\title{
Distribuition Of CRUSTOSE CORALline ALgae (CoRallinales, RHODOPHYTA) IN THE ABrolHos REEFs, BAHIA, BrAZIL
}

\author{
Frederico Tapajós de Souza Tâmega ${ }^{1,2}$ \& Marcia A. O. Figueiredo ${ }^{1}$
}

\begin{abstract}
(Distribuition of crustose coralline algae (Corallinales, Rhodophyta) in the Abrolhos reefs, Bahia, Brazil) The crustose coralline algae have an important structural role in coral reef crests, as observed for some Atlantic reefs. In this work the distribution and abundance of crustose coralline algae and their relation to other benthic reef organisms were described for the Abrolhos Archipelago. The quantification of sessile organisms was made by SCUBA diving along replicated transect lines in different habitats and sites. Anovas were performed to test differences on algae abundance among sites and habitats. Coralline crusts did not show significant differences on abundance among sites (Anova, $\mathrm{p}>0,05$ ), neither other benthic organisms (Anovas, $\mathrm{p}=0,634$ invertebrates, $\mathrm{p}=0,767$ filamentous algae, $\mathrm{p}=0,581$ foliose algae, $\mathrm{p}=0,070$ leathery algae and $\mathrm{p}=0,616$ non calcareous crusts). Invertebrates and filamentous algae were the most abundant organisms on all sites and most habitats, contrasting with the low cover of coralline algae. In sheltered sites and on reef base it was observed a trend for an increase of fleshy foliose algae and leathery algae, contrasting with wave exposed sites. The distribution of coralline growth forms was characterized by a higher abundance of flat in relation to branched thalli. Branched coralline crusts are apparently more abundant within cryptic reef areas, not necessarily because of light limitation, but probably due to less herbivore pressure. Keywords: crustose coralline algae, distribution, reef habitats.

\section{RESUMO}

(Distribuição das algas calcárias incrustantes (Corallinales, Rhodophyta) nos recifes dos Abrolhos, Bahia, Brasil) As algas calcárias incrustantes possuem importante papel estrutural nas cristas recifais, como observado para alguns recifes do Atlântico. Neste trabalho, a distribuição e abundância das algas calcárias incrustantes em relação a outros organismos bênticos recifais foi descrita para o Arquipélago dos Abrolhos. A quantificação dos organismos sésseis foi por mergulho autônomo em transectos replicados em diferentes locais e habitats. Anovas foram usadas para testar diferenças na abundância das algas entre locais e habitats. Não foram observadas diferenças significativas entre locais nem na abundância de crostas calcárias (Anova, $p>0,05$ ) nem de outros organismos (Anovas, $\mathrm{p}=0,634$ invertebrados, $\mathrm{p}=0,767$ algas filamentosas, $\mathrm{p}=0,581$ algas foliáceas, $\mathrm{p}=0,070$ algas coriáceas). Invertebrados e algas filamentosas foram os organismos mais abundantes em todos os locais e maioria dos habitats, contrastando com a baixa cobertura de crostas calcárias. Nos locais abrigados e na base dos recifes, foi observada uma tendência para aumento de algas foliáceas pouco rígidas e algas coriáceas, contrastando com locais mais expostos às ondas. A distribuição dos morfótipos de crostas calcárias foi caracterizada pela alta abundância de talo plano em relação ao talo ramificado. As crostas calcárias ramificadas são aparentemente mais abundantes nas partes crípticas dos recifes, não necessariamente pela limitação da luz, mas provavelmente devido a uma menor pressão de herbivoria.
\end{abstract}

Palavras-chave: algas calcárias incrustantes, distribuição, habitats recifais.

\section{INTRODUCTION}

The crustose coralline algae (Corallinalles Rhodophyta) are worldwide distributed from polar to tropical regions, occupying intertidal regions to great depths where light is not yet absent (Steneck 1986). On coral reefs, these crustose algae can cover large areas, such as in the Caribbean (Adey \& Vassar 1975) and Brazil (Villaça \& Pitombo 1997; Figueiredo 1997, 2000;
Figueiredo \& Steneck 2002). Studies confirmed that crustose coralline algae are an important component of reef framework together with corals and other organisms in shallow environments exposed to strong wave action, as reported to some Atlantic Caribbean (Macintyre 1997) and Brazilian reefs (Kikuchi \& Leão 1997; Leão and Dominguez 2000; Gherardi and Bosence 2001; Leão \& Kikuchi 2001).

Artigo recebido em 05/2007. Aceito para publicação em 10/2007.

${ }^{1}$ Instituto de Pesquisas Jardim Botânico do Rio de Janeiro, Programa Zona Costeira, Rua Pacheco Leão 915, 22460-230, Rio de Janeiro, RJ.

${ }^{2}$ Programa de Pós-Graduação em Botânica, Museu Nacional - UFRJ, Quinta da Boa Vista s/no, 20940-040, Rio de Janeiro, RJ. ftapajos@jbrj.gov.br 
According to models of form and function proposed to describe the distribution and abundance of macroalgae, crustose coralline algae are classified as a unique group that dominates within highly productive environments exposed to high levels of disturbance (Littler \& Littler 1980, 1984; Steneck \& Dethier 1994). Morphological characteristics of coralline algae indicate adaptations to many environmental and biological factors, such as wave exposure, light intensity, sediment deposition, competition and herbivory (Steneck 1986; Steneck \& Dethier 1994). In fact, several descriptive studies have related patterns of distribution and abundance of these algae to environmental parameters that influence coral reefs (Adey \& Vassar 1975; Littler et al. 1995; Steneck 1997; Fabricius \& De' ath 2001; Figueiredo \& Steneck 2002).

Among crustose coralline algae there are several morphological groups according to thallus degree of branching, thickness and margin adherence to substratum (Steneck 1986). Two species commonly found on the Atlantic Ocean reefs, Porolithon pachydermum (Foslie) Foslie and Lithophyllum congestum (Foslie) Foslie (Adey 1975; Steneck \& Adey 1976), can be easily distinguished by their flat and branched growth forms, respectively. In the southernmost Atlantic reefs they are found in shallow habitats, sharing space with other sessile organisms (Figueiredo 1997; Villaça \& Pitombo 1997; Figueiredo \& Steneck 2002; Figueiredo 2006). In order to understand the distribution and abundance of these two coralline growth forms, this study aims to describe their relative abundance to other benthic organisms in different sites and reef habitats of the Abrolhos Archipelago, regarding some environmental parameters that might influence their growth and survival.

\section{Material and Methods \\ Sites descriptions}

The Abrolhos Archipelago is part of a Brazilian Marine National Park located at $17^{\circ} 57^{\prime}-17^{\circ} 59^{\prime} \mathrm{S}$ and $38^{\circ} 41^{\prime}-38^{\circ} 43^{\prime} \mathrm{W}$ (Fig. 1). The average seawater temperature ranges from 23 to $27^{\circ} \mathrm{C}$ (Muehe 1988) and salinity around 36.5 to 36.7 (Muehe 1988). In autumn and winter

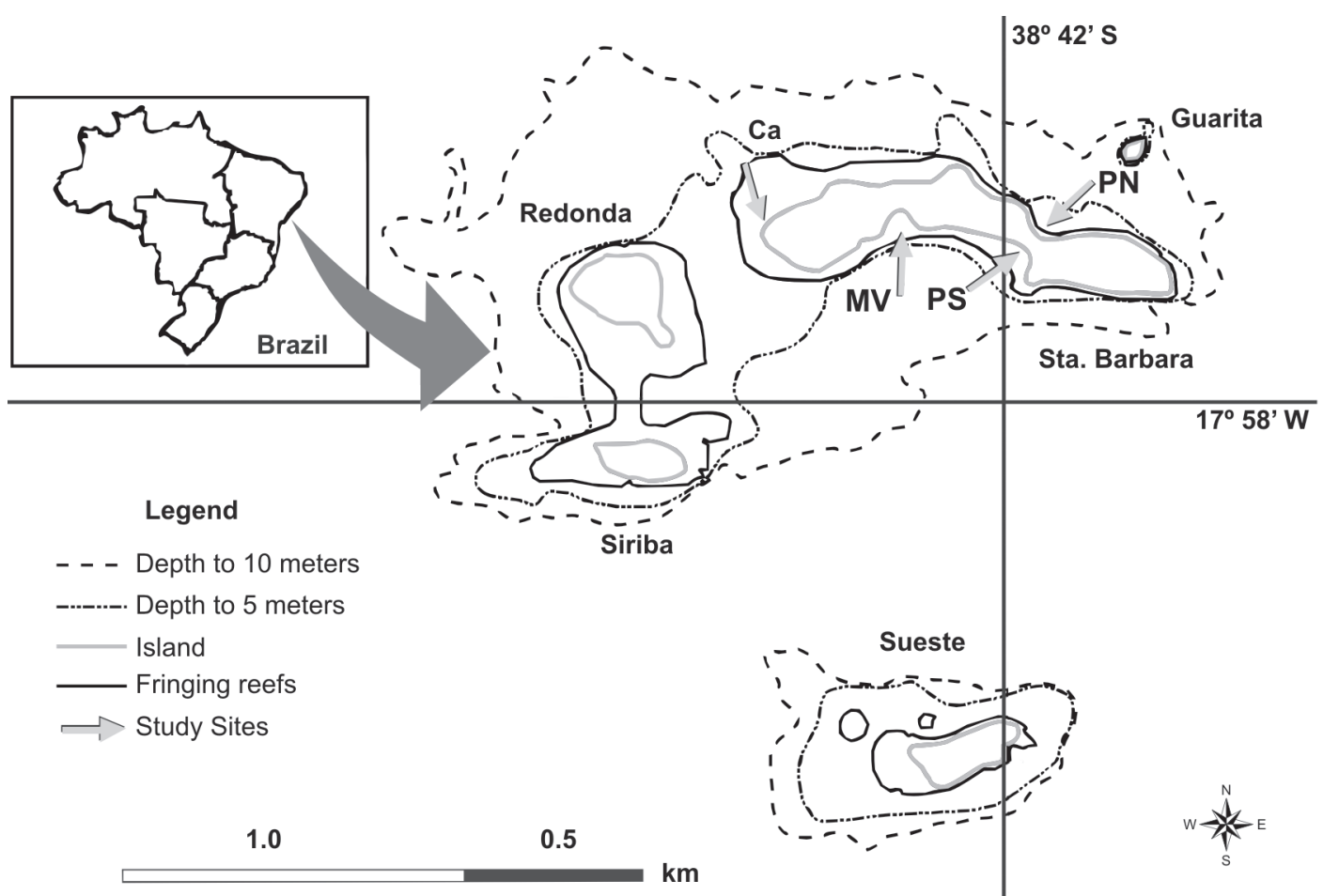

Figure 1 - Location of the study sites at Santa Barbara island: Porto Norte (PN), Caldeiros (Ca), Mato Verde (MV) and Porto Sul (PS). 
(from March to September), winds are mostly from south. In spring and summer (September to February), winds are from east to north. Tides range from 2.4 to 0.1 towards the north (Porto de Ilheus) and 1.8 to 0.0 in the south (Barra do Riacho) (Muehe 1988).

Four study sites were chosen along Santa Barbara Island according to reef orientation: Porto Norte (N), Calderos (NW), Mato Verde (SW) and Porto Sul (S) (Fig. 1). Three habitats were studied: reef flat, reef edge and reef base in Mato Verde. Reef flat is usually exposed to air in extreme spring low tides and reef base is around 4 to $5 \mathrm{~m}$ depth. Reefs have a shallow slope in Porto Norte and Porto Sul, while at Calderos and Mato Verde they have a steep slope. Sites were compared only at reef edge, where corallines are more abundant (Figueiredo 1997). Samples were collected during the period of $4 / 12 / 2001$ to $9 / 03 / 2002$ in summer and 4/07/ 2002 to $20 / 10 / 2002$ in winter.

The specimens of crustose coralline algae were sampled on the reef edges of four study sites by SCUBA diving. Samples were removed with hammer and chisel and stored in nylon mesh bags.

To quantify the abundance of coralline algae and other sessile organisms three parallel transect lines, measuring $10 \mathrm{~m}$ length with 30 random intercept points, placed at intervals of $1 \mathrm{~m}$ amongst themselves, were used for each reef sites. Only in Mato Verde three transect lines were added on the reef flat and reef base. On each transect line point only the closest specimen was sampled. The minimum number of points for a transect was based on Figueiredo and Steneck (2002) \& Figueiredo (2006). Samples were preserved in $4 \%$ formaline seawater solution and other part air dried at dark to maintain their thallus color. Using a stereomicroscope the morphological characteristics of the thalli were observed, as presence of protuberances or branches, thallus thickness, margin adherence and size and shape of reproductive conceptacles. The coralline samples with similar characteristics were separated in growth forms following the classification of form-functional groups proposed by Steneck (1986).

Statistical analysis was performed to test differences on algae abundance among habitats and sites. The normality of data was assumed due to the low number of samples. To test the homogeneity of variances, Cochran's test was applied before the analysis of variances (Anova). Percentual cover data were arcsine transformed before Anova was performed (Zar 1984).

\section{Results}

The crustose coralline algae did not exceed $20 \%$ of total substratum cover, considering only crusts free of epiphytes. In general, there was a strong trend for a high abundance of flat in relation to branched coralline thalli in all studied sites (Fig. 2). When the cover of flat coralline algae was compared

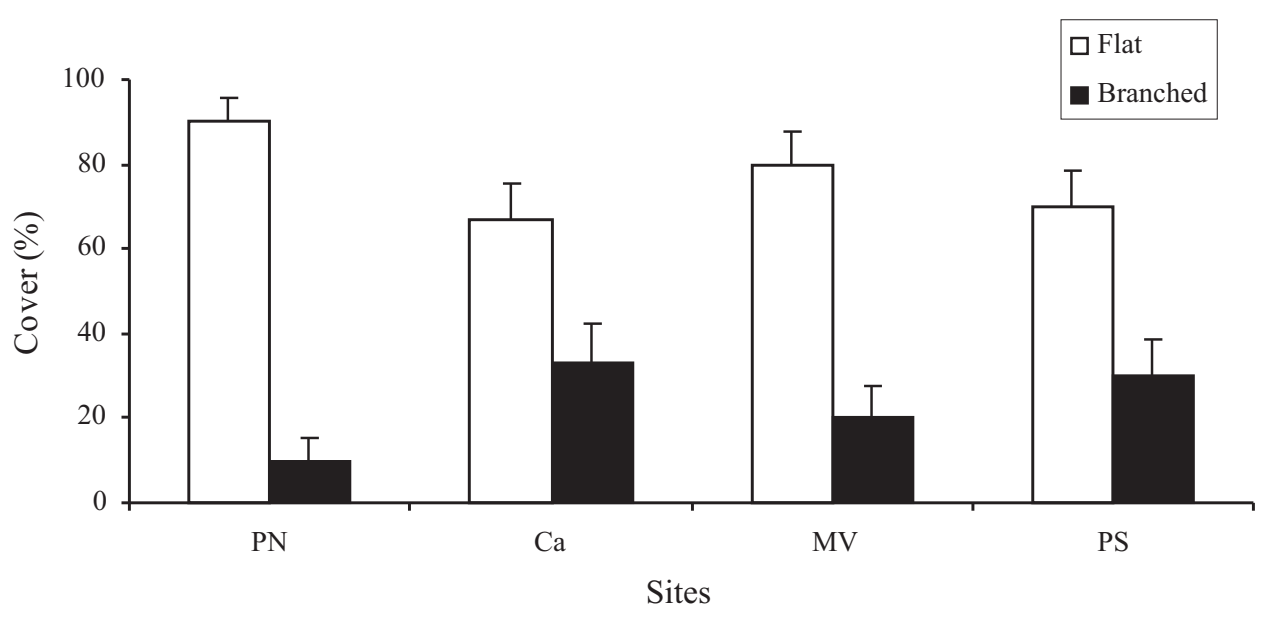

Figure 2 - Abundance in percentage cover of flat and branched growth forms of crustose coralline algae in the studied sites: Porto Norte (PN), Calderos (Ca), Mato Verde (MV) and Porto Sul (PS). 
among all studied sites, a significant difference was not observed and a similar pattern was found for branched coralline algae (Anovas, $\mathrm{p}>0,05$ ).

Other macroalgae were found close to or upon crustose coralline algae, such as the filamentous brown Sphacelaria tribuloides Meneghini and Hincksia mitchelliae (Harvey) P.C. Silva, the filamentous green Cladophora spp. and the filamentous red Polysiphonia spp., Centroceras clavulatum (C. Agardh) Montagne and Ceramium spp. There was also the foliose brown algae Stypopodium zonale (J. V. Lamouroux) Papenfuss, Padina spp. and Dictyota spp., the leathery Sargassum spp. and other non calcareous brown crusts. Among the more common benthic invertebrates there were stony corals, such as Mussismilia braziliensis, zoanthids, mainly Palythoa caribbeorum, and few unidentified sponges / ascidians.

There was a trend for a high cover of sessile invertebrates and filamentous algae in relation to crustose coralline algae in all study sites (Fig. 3). However, significant differences among sites were not found for any organism (Anova, $\mathrm{p}=0,634$ for invertebrates, $\mathrm{p}=0,767$ for filamentous algae, $\mathrm{p}=0,581$ for fleshy foliose algae, $\mathrm{p}=0,07$ for leathery algae, $p=0,931$ for non calcareous crusts and $\mathrm{p}=0,616$ for coralline crusts).
When comparing the abundance of organisms among three habitats, significant differences were not found for most groups (Fig. 4, Anova $\mathrm{p}=0,103$ for invertebrates, $p=0,110$ for filamentous algae, $p=0,421$ for non calcareous crusts and $\mathrm{p}=0,673$ for coralline crusts), except for fleshy foliose algae (Anova $\mathrm{p}=0,042)$ and leathery algae (Anova $\mathrm{p}=0,048)$ that were more abundant on reef base. There is a trend for a high cover of sessile invertebrates and filamentous algae on reef flat and reef edge, respectively.

\section{Discussion}

Considering the distribution of organisms in mature communities, one main factor that can influence abundance and form of algae is the action of winds and consequent waves (Kain \& Norton 1990; Norton 1991; Hurd 2000). Despite a gradual change in the degree of wave exposure, all study sites were dominated by sessile invertebrates and filamentous algae, contrasting with the low cover of crustose coralline algae and other macroalgae. The fast growing opportunistic algae (filamentous algae) are usually more abundant than other algae for being able to quickly build biomass that has been lost after environmental disturbances (Steneck \& Dethier 1994). In the

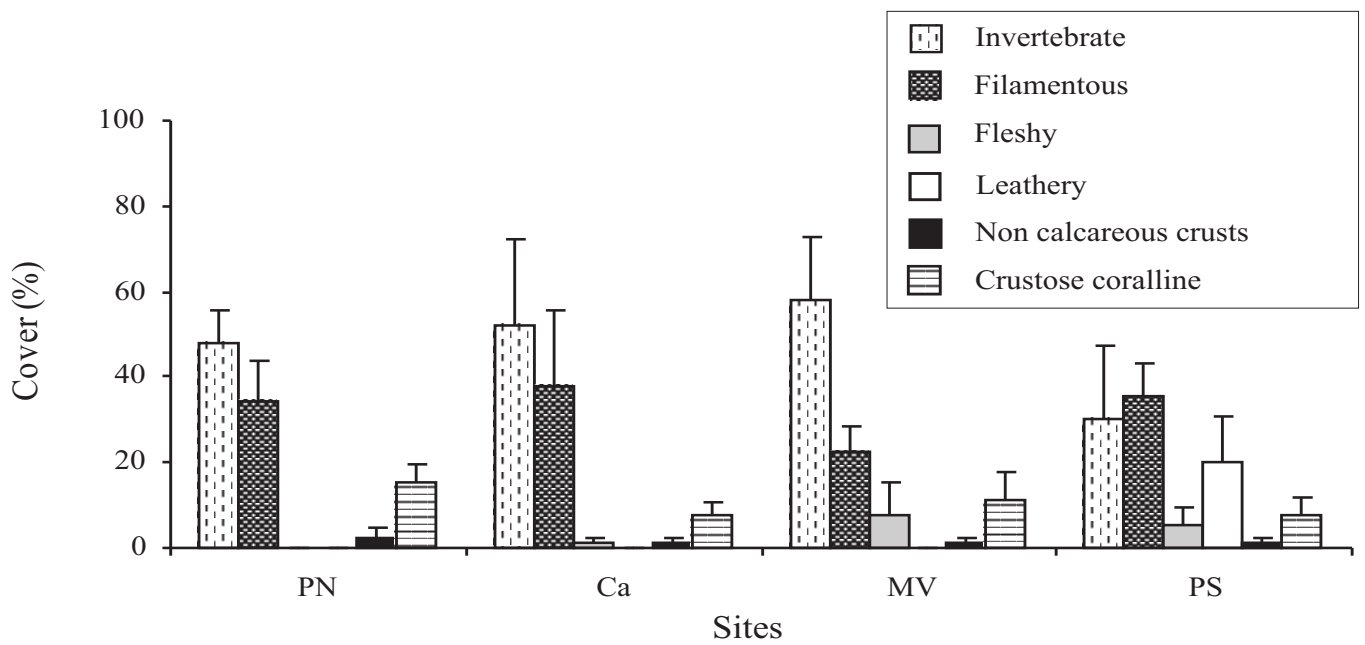

Figure 3 - Abundance in percentage cover of sessile organisms in the studied sites: Porto Norte (PN), Calderos (Ca), Mato Verde (MV) e Porto Sul (PS). 


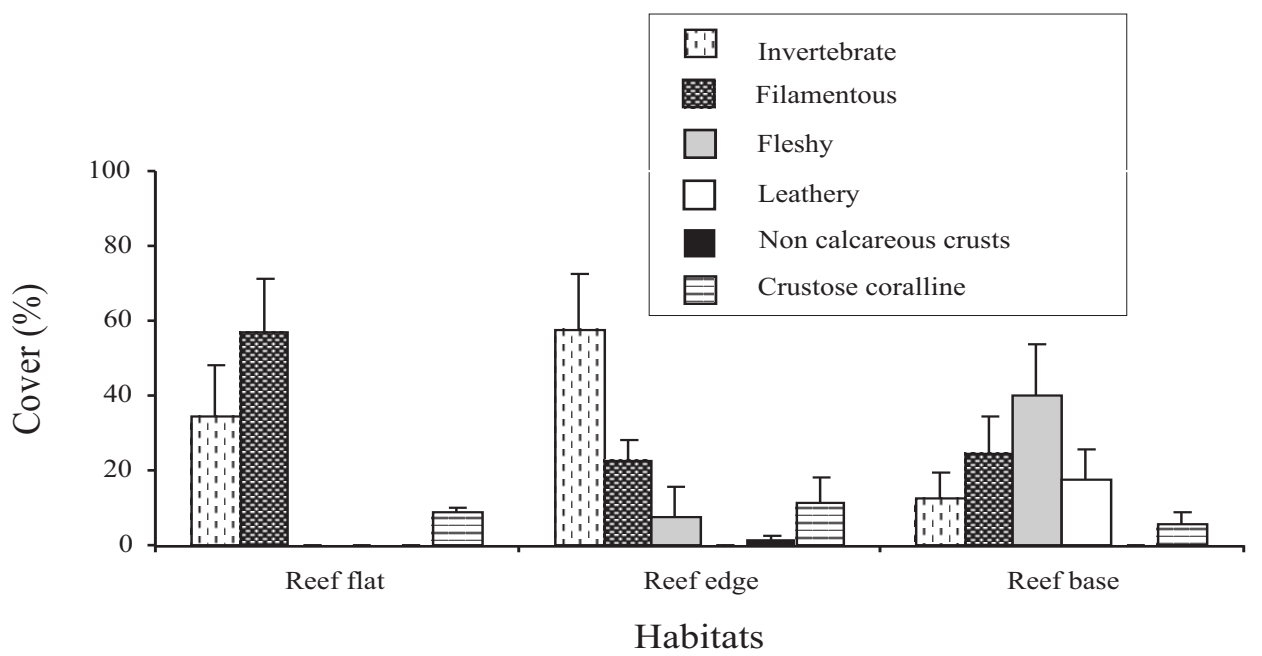

Figure 4 - Abundance in percentage cover of sessile organisms in reef habitats at Mato Verde: reef flat, reef edge and reef base.

sheltered sites of Mato Verde and Porto Sul, it was observed a trend for an increase in the abundance of fleshy foliose and leathery algae. The same did not happen at the wave exposed sites of Porto Norte and Calderos, probably because waves removed those algae from reef substratum. The distribution and abundance of organisms found at sheltered studied sites agree with algae distribution patterns described for Abrolhos Archipelago by Villaça \& Pitombo (1997) and Figueiredo (1997), except that the crustose coralline algae were found in higher abundance by the latter because survey methods included the quantification of crusts covered and free of epiphytes.

When comparing different habitats in Mato Verde, only the reef flat and reef edge had the same pattern of filamentous algae or sessile invertebrate dominance with a low cover of crustose coralline algae. Therefore, it was suggested that there might be another limiting factors acting besides wave action, such as desiccation during spring low tide. On the reef base constantly submerged there was an increase in fleshy foliose and leathery algae. Filamentous algae, such as Ceramium and Polysiphonia, may be considered less resistant to desiccation because they quickly loose thallus water, due to a high area to volume ratio (Kain \& Norton 1990). However, they may form turfs that keep great amount of sediments and water between entangled filaments, thus becoming less susceptible to desiccation than other macroalgae (Wanders 1977). The crustose coralline algae and non calcareous crusts did not differ in their abundance among studied habitats. In contrast, a reduction of crustose coralline algae cover on reef base was previously observed on another Island of the Archipelago (Sueste) by Figueiredo (1997). This can be related to shade due to a dense canopy of fleshy algae on its reef base that cut off light beneath to crustose coralline algae (Figueiredo \& Steneck 2002). In fact, fleshy foliose algae were not found on the reef base together with coralline crusts in the studied site at Santa Barbara Island.

In the Archipelago of Abrolhos, shallow reef areas are dominated by two coralline crusts growth forms, Porolithon pachydermum and Lithophyllum congestum (Figueiredo \& Steneck 2002). P. pachydermum belongs to the sub-family Masthophoroideae Setchell 1943, that is characterized by the absence of genicula, cells united sideways by fusion, secondary cellular pit connections absent or rare, tetrasporangia and bisporangia conceptacles uniporated and blocked by plugs. L. congestum belongs to the subfamily Lithophylloideae Setchell 1943, that it is characterized by the absence of genicula, cells united by secondary pit connections, cels 
fusion absent or rare, tetrasporangia and bisporangia conceptacles uniporate and unblocked (Woelkerling 1988).

On the sunlit reef edge, the distribution of crustose coralline algae was characterized by a high abundance of the flat thallus of $P$. pachydermum in relation to the branched L. congestum crust, probably favoured by high levels of irradiance (Littler 1973). The branched coralline crusts are apparently more abundant within reef crevices, grooves and edges and on shaded surfaces of the reef (areas with a steep slope, more than $180^{\circ}$ ). In fact, $L$. congestum requests turbulent waters and high light levels to develop branches with fused forms (Adey 1975), but its thallus branches can be easily spotted and consumed by parrotfishes (Steneck \& Adey 1976). In general, competition for space among species of crustose coralline algae is known to be regulated by the intrinsic capacity of marginal growth, acting together or separately with the light, temperature and herbivory (Adey 1970, Fabricius \& De'ath 2001).

In summary, dominant benthic organisms in shallow waters of Abrolhos Archipelago are sessile invertebrates and filamentous algae, being coralline crusts less abundant. The degree of wave exposure did not seem to limit or enhance the distribution of crustose coralline algae. Flat unbranched thalli of the crustose coralline algae P. pachydermum are more abundant than the branched form of L. congestum, probably because they are less susceptible to be consumed by herbivorous fishes.

\section{ACKNOWLedgments}

We would like to thanks the staff of the National Marine Park of Abrolhos who supported field work, Abrolhos Turismo for helping with boat transportation and the Brazilian Navy for their hospitality. Coordenação de Aperfeiçoamento de Pessoal de Nível Superior-CAPES has given a MSc scholarship to the first author and Instituto Brasileiro do Meio Ambiente - IBAMA issued a research the license for collecting samples. We are grateful to Andrea Franco de Oliveira at LAGIEF/IEF-RJ for help with the map.

\section{REFERENCES}

Adey, W. H. 1970. The effects of light and temperature on growth rates in boreal-

subartic crustose coralline algae. Journal of Phycology 6: 269-276.

1975. The algal ridges and coral reefs of St. Croix, their structure and Holocene development. Atoll Reasearch Bulletin 187: 1-66.

\& Vassar, J. M. 1975. Colonization, succession and growth rates of tropical crustose coralline algae (Rhodophyta, Cryptonemiales). Phycologia 14: 55-69.

Fabricius, K. \& De'ath, G. 2001. Enviromental factors associated with the spatial distribution of crustose coralline algae on the Great Barrier Reef. Coral Reefs 19: 303-309.

Figueiredo, M. A. O. 1997. Colonization and growth of crustose coralline algae in Abrolhos, Brazil. Proceedings of the 8th International Coral Reef Symposium 1: 689-694.

2000. Recifes de corais ou recifes de algas. Ciência Hoje 28(166): 74-76.

2006. Diversity of macrophytes in the Abrolhos bank. In: Allen, G.; Dutra, G. F.; Werner, T. B. \& Moura, R. L. (eds.). A biological assessment of the Abrolhos bank, Brazil. R.A.P. Bulletin Biological Assessment. Conservation International, Pp. 67-74.

\& Steneck, R. S. 2002. Floristic and ecological studies of crustose coralline algae on Brazil's Abrolhos reefs. In: Proceedings of the 9th International Coral Reef Symposium. Pp. 493-498.

Gherardi, D. F. M. \& Bosence, D. W. J. 2001. Composition and community structure of the coralline algal reefs from Atol das Rocas, South Atlantic, Brazil. Coral Reefs 19: 205-219.

Hurd, C. L. 2000. Water motion, marine macroalgal physiology, and production. Journal of Phycology 36: 453-472.

Kain, J. M. \& Norton, T. A. 1990. Marine ecology. In: Cole, K. M. \& Sheath, R. 
(eds.). The Biology of the Red Algae. Cambridge University Press, Cambridge, Pp. 377-422.

Kikuchi, R. K. P. \& Leão, Z. M. A. N. 1997. Rocas (Southwestern Equatorial Atlantic, Brazil): an atol built primarily by coralline algae. In: Proceedings of the 8th International Coral Reefs Symposium 1: 731-736.

Leão Z. M. A. N., Dominguez J. M. L. 2000. Tropical coast of Brazil. Marine Pollution Bulletin 41: 112-122.

\& Kikuchi, R. K. P. 2001. The Abrolhos reefs of Brazil. Ecological Studies 144: 83-96.

Littler M. M. 1973. The population and community structure of Hawaiian fringingreef crustose corallinaceae (Rhodophyta, Cryptonemiales). Journal of Experimental Marine Biology and Ecology 11: 103-120 \& Littler, D. S 1980. The evolution of thallus form and survival strategies in benthic marine macroalgae: field and laboratory tests of a functional form model. The American Naturalist 116: 25-44.

\& Littler, D. S. 1984. Relationships between macroalgal functional form groups and substrata stability in a subtropical rocky intertidal system. Journal of Experimental Marine Biology and Ecology 74: 13-34.

; Littler D. S. \& Taylor P. R. 1995. Selective herbivore increases biomass of its prey: a chiton-coralline reef-building association. Ecology 76(5): 1666-1681.

Macintyre, I. G. 1997. Reevaluating the role of crustose coralline algae in the construction of the coral reefs. In: Proceedings of the 8th International Coral Reef Symposium 1: 725-730.

Muehe, D. 1988. O arquipélago dos Abrolhos: geomorfologia e aspectos gerais. Anuário do Instituto de Geociências. Pp. 90-100.

Norton, T. A. 1991. Conflicting constraints on the form of intertidal algae. British Phycological Journal 26: 203-218.

Steneck, R. S. 1986. The ecology of coralline algal crusts: convergent patterns and adaptive strategies. Annual Review of Ecological Systematics 17: 273-303. 1997. Crustose corallines, other algal functional grups, herbivores and sediments: complex interactions along reef productivity gradients. Proceedings of the 8th International Coral Reefs Symposium 1: 695-700.

\& Adey, W. H. 1976. The role of environment in control of morphology in Lithophyllum congestum, a Caribbean algal ridge builder. Botanica Marina 19: 197-215.

\& Dethier, M. N. 1994. A functional group approach to the structure of algaldominated communities. Oikos 69:476-498.

Villaça, R. \& Pitombo, F. B. 1997. Benthic communities of shallow-water reefs of Abrolhos, Brazil. Revista Brasileira de Oceanografia 45 (1/2): 35-43.

Wanders, J. B. W. 1977. The role of benthic algae in the shallow reef of Curacao (Netherlands Antilles) III: The significance of grazing. Aquatic Botany 3: 357-390.

Woelkerling, W. J. 1988. The coralline red algae: an analysis of the genera and subfamilies of nongeniculate Corallinaceae. British Museum Natural History and Oxford University Press, London and Oxford, 268p.

Zar, J. H. 1984. Biostatiscal analysis. $2^{\text {nd }}$ ed. Prentice-Hall International, London, 718pp. 